\title{
LARGE-SCALE SOIL HEALTH RESTORATION THE WAY FORWARD FOR REVERSING CLIMATE CHANGE WHILE ENHANCING FOOD AND NUTRITION SECURITY
}

Sununtar Setboonsarng and Elsbeth E. Gregorio

NO. 16

November 2017

\section{ADB SOUTHEAST ASIA WORKING PAPER SERIES}


ADB Southeast Asia Working Paper Series

\section{Large-Scale Soil Health Restoration: \\ The Way Forward for Reversing Climate Change while Enhancing Food and Nutrition Security}

Sununtar Setboonsarng and Elsbeth E. Gregorio No. 16 | November 2017
Sununtar Setboonsarng is a former principal natural resources and agriculture economist at the Southeast Asia Department, Asian Development Bank.

Elsbeth E. Gregorio is a former research associate at the Asian Development Bank Institute and consultant for the Core Agriculture Support Program of the Asian

Development Bank. 
(C) 2017 Asian Development Bank

6 ADB Avenue, Mandaluyong City, 1550 Metro Manila, Philippines

Tel +632632 4444; Fax +6326362444

www.adb.org

Some rights reserved. Published in 2017.

Publication Stock No. WPS179128-2

DOI: http://dx.doi.org/10.22617/WPS179128-2

The views expressed in this publication are those of the authors and do not necessarily reflect the views and policies of the Asian Development Bank (ADB) or its Board of Governors or the governments they represent.

$A D B$ does not guarantee the accuracy of the data included in this publication and accepts no responsibility for any consequence of their use. The mention of specific companies or products of manufacturers does not imply that they are endorsed or recommended by ADB in preference to others of a similar nature that are not mentioned.

By making any designation of or reference to a particular territory or geographic area, or by using the term "country" in this document, $A D B$ does not intend to make any judgments as to the legal or other status of any territory or area.

This work is available under the Creative Commons Attribution 3.0 IGO license (CC BY 3.0 IGO) https://creativecommons.org/licenses/by/3.0/igo/. By using the content of this publication, you agree to be bound by the terms of this license. For attribution, translations, adaptations, and permissions, please read the provisions and terms of use at https://www.adb.org/terms-use\#openaccess

This CC license does not apply to non-ADB copyright materials in this publication. If the material is attributed to another source, please contact the copyright owner or publisher of that source for permission to reproduce it. ADB cannot be held liable for any claims that arise as a result of your use of the material.

Please contact pubsmarketing@adb.org if you have questions or comments with respect to content, or if you wish to obtain copyright permission for your intended use that does not fall within these terms, or for permission to use the ADB logo.

Notes:

In this publication, "\$” refers to US dollars.

ADB recognizes "China" as the People's Republic of China, and "Vietnam" as Viet Nam.

Corrigenda to ADB publications may be found at http://www.adb.org/publications/corrigenda 


\section{CONTENTS}

TABLES

ABSTRACT $v V$

ABBREVIATIONS Vi

$\begin{array}{ll}\text { I. INTRODUCTION } & 1\end{array}$

II. IMPORTANCE OF SOIL HEALTH TO MAN AND CLIMATE 2

III. BRIEF EVOLUTION OF AGRICULTURE PRACTICES 3

A. The Green Revolution and Modern Agricultural Practice 3

B. Issues in the Current Agricultural Practice 5

IV. CONVENTIONAL AGRICULTURAL PRACTICES IN THE GREATER MEKONG SUBREGION

A. Issues of Modern Agriculture in the Greater Mekong Subregion 8

V. REINVENTING AGRICULTURE

A. Soil Biology and the Soil Food Web 11

B. Regenerative Agriculture, Soil Biology, and Carbon Sequestration 12

C. Biodiversity in Soil Organisms and Its Benefits $\quad 12$

D. Evidence on Benefits of Healthy Soil 14

E. $\quad$ Fostering Soil Biology toward Healthy Soil 15

F. $\quad$ Farming Practices that Improve Soil Health in the Greater Mekong

G. Composting and Its Benefits 19

VI. POLICY RECOMMENDATIONS TO PROMOTE HEALTHY SOILS 21

$\begin{array}{ll}\text { CONCLUSION } & 22\end{array}$ 


\section{TABLES}

$1 \quad$ Global Fertilizer Consumption 6

$2 \quad$ Population in the Greater Mekong Subregion, 2014

$3 \quad$ Productivity Indicators, 2007-2011 8

$4 \quad$ World's Top Rice Exporters, 2015

5 Production of Ammonia $\quad 9$

6 Greenhouse Gas Emissions in the Greater Mekong Subregion

7 Assessment of Ecosystem Productivity 15 


\begin{abstract}
This paper discusses soil health and provides soil-regenerative agriculture practices that can mitigate and revers climate change; improve water management (flood, drought, water purification, etc.); and enhance food and nutrition security.

Soils not only have a key role in fulfilling specific nutritional needs of plants. Soil also performs many ecosystem services, including carbon sequestration; water purification and soil contaminant reduction; climate regulation; nutrient cycling; providing a habitat for organisms; flood regulation; producing genetic resources and pharmaceuticals; and providing food, fuel and fiber.

World leaders have recognized that initiatives to limit temperature rise to less than 2 degrees Celsius $\left({ }^{\circ} \mathrm{C}\right)$ compared to preindustrial levels must start now. Under the Lima-Paris Action Agenda, France launched the 4 Per 1000 Initiative with the support of the Food and Agriculture Organization of the United Nations (FAO). The initiative highlights the necessary role soil plays in a comprehensive effort to fight climate change, with the objective of increasing carbon sequestration in agricultural soil-which can lead to food security by increasing soil fertility, improving adaptation capacity of agriculture to climate change, and mitigating greenhouse gas emissions.

Research on promotion of healthy soils should be focused on four complementary themes: (i) mechanisms and assessment of carbon storage potential in soils across regions and systems; (ii) performance evaluation of best farming practices for soil carbon and impact on other greenhouse gases, food security, and other regulation and production services; (iii) innovation and its promotion by appropriate policies; and (iv) monitoring and estimating variations in soil carbon stock, especially at the farmer level.
\end{abstract}




\section{ABBREVIATIONS}

$\begin{array}{lll}\text { AMF } & - & \text { arbuscular mycorrhizal fungi } \\ \mathrm{CO}_{2} & - & \text { carbon dioxide } \\ \text { FAO } & - & \text { Food and Agriculture Organization of the United Nations } \\ \text { GHG } & - & \text { greenhouse gas } \\ \text { GMS } & - & \text { Greater Mekong Subregion } \\ \text { INDCs } & - & \text { Intended Nationally Determined Contributions } \\ \text { Lao PDR } & - & \text { Lao People's Democratic Republic } \\ \text { NGO } & - & \text { nongovernment organization } \\ \text { PRC } & - & \text { People's Republic of China } \\ \text { SOM } & - & \text { soil organic matter } \\ \text { SRI } & - & \text { system of rice intensification }\end{array}$




\section{INTRODUCTION}

1. Soil is a complex system of inorganic and organic materials, living organisms, water, and air. It is home to more than one trillion species of microbes, which are life forms too small to be seen with the naked eye, including bacteria and fungi. Soil is considered nonrenewable as it takes hundreds or even thousands of years to form a centimeter of top soil.

2. Soil has been overlooked as a natural resource. While the role of soil in food production is well recognized, little is understood on the role of soil to improve flood and drought resilience, and water use efficiency; nor its ability to sequester atmospheric carbon, and provide minerals and micronutrients in food. By overlooking this important nonrenewable resource, many great opportunities to improve our future may have been missed out.

3. The contribution of soils in mitigating climate change is increasingly advocated and recognized. This role has been undermined by modern agricultural practices that deplete soil carbon stocks. Anthropogenic greenhouse gas emissions (GHG) have been raising recorded temperatures since the Industrial Revolution. GHG emissions from agriculture, forestry, and fisheries have almost doubled in the last 50 years and will increase by $30 \%$ by 2050 given the current trend. The primacy of arresting climate change is nowhere more evident than the adoption of 195 countries of the first legally binding global climate deal at the Paris Climate Conference, or COP21, in December 2015. With atmospheric carbon dioxide $\left(\mathrm{CO}_{2}\right)$ reaching 400 parts per million in 2016 soils can be an ally in bringing the $\mathrm{CO}_{2}$ level down to a sustainable level. ${ }^{1}$

4. World leaders recognize that initiatives to limit temperature rise to less than 2 degrees Celsius $\left({ }^{\circ} \mathrm{C}\right)$ compared to preindustrial levels must start now. Spearheaded by the governments of France and Peru, the Lima-Paris Action Agenda was launched to bring state and nonstate actors to accelerate global cooperative climate action ahead of the Paris conference that brought universal climate change agreement among 195 governments. Under the Lima-Paris Action Agenda, France launched the 4 Per 1000 Initiative with the support of the Food and Agriculture Organization of the United Nations (FAO). The initiative highlights the necessary role soil plays in a comprehensive effort to fight climate change, with the objective of increasing carbon sequestration in agricultural soil-which can lead to food security by increasing soil fertility, improving adaptation capacity of agriculture to climate change, and mitigating greenhouse gas emissions.

5. This paper discusses the importance of soil health as carbon sink and its potential to reverse climate change. It examines the evolution of agriculture practices and uses statistics, primarily from the countries of the Greater Mekong Subregion (GMS), to show how the current agricultural practices are affecting the environment and the climate. The paper describes what constitutes soil health and regenerative agriculture practices that can be promoted as a strategy to mitigate and reverse climate change; improve water management (flood, drought, water purification, etc.); and enhance food and nutrition security.

Kahn, B. 2016. The World Passes 400 ppm Threshold. Permanently. The Climate Central. 27 September http://www.climatecentral.org/news/world-passes-400-ppm-threshold-permanently-20738 (accessed September 2017). 


\section{IMPORTANCE OF SOIL HEALTH TO MAN AND CLIMATE}

6. The year 2015 was declared by the United Nations General Assembly as the International Year of Soils. The initiative aimed to raise awareness worldwide on the important roles that soils play in slowing climate change, securing food supply, and enhancing plant biodiversity. Soil is encountered in daily life, which may have made it easy to overlook the essential ecosystem services it provides.

7. Indeed, healthy soil is ever more important in our warming climate as it increases the adaptive capacity of plants to withstand extreme weather conditions, lessening crops failures. Thus, healthy soil helps address the challenge of feeding the planet's ever growing population that is estimated to increase to 9.6 billion by $2050,{ }^{2}$ while enhancing resilience and sustainability of productive bases. Healthy soil is also essential in the fight to end malnutrition, particularly in rural areas. Malnutrition remains the main cause of death for children under the age of five. ${ }^{3}$ Healthy soil is promoted in organic farming, which has been found to yield more nutritious crops. A review of 343 studies in 2014 has revealed higher nutrient values from organic produce than from conventional farming. ${ }^{4}$ This can directly address nutritional deficiencies for urban consumers and poor farmers.

8. Changing the way agriculture is currently practiced to climate-friendly practices allows soil to regain its role as the planet's key reservoir of carbon, and to hold potential for expanded carbon sequestration. With proper soil management, soil is estimated to sequester around 20 petagrams of carbon in 25 years, roughly over 10\% of the anthropogenic emissions. Appropriate soil management practices regenerate soils, which can help sequester carbon from the atmosphere.

9. Carbon sequestration in managed soil happens when there is a net removal of atmospheric $\mathrm{CO}_{2}$ because carbon inputs (e.g., crop residues) exceed carbon outputs (e.g., harvested materials, carbon emissions from fuel and manufacture of fertilizers). ${ }^{5}$ The higher the amount of organic carbon in soil, the higher the fertility of soil, increasing yields that can enhance food security. Higher organic carbon content helps to mitigate the effects of rising temperatures and water scarcity, which decrease yields, particularly in low latitude and tropical regions. ${ }^{6}$ More frequent dry spells will severely endanger the yields of $82 \%$ of 1.5 billion hectares of rainfed farmland worldwide. ${ }^{7}$ Irrigated farmlands also suffer as surface water sources and reservoirs dry up. Droughts and dry spells from the El Niño phenomenon in 2015 delayed the rice planting season in Asia, which raised prices, and global rice output is expected to decrease for the first time in 6 years. ${ }^{8}$

10. Climate change can bring irreversible damage to the planet and the lives of its peoples. Soil can become a part of the solution to climate change and food security. The pressing task of making

2 United Nations News Center. 2013. World Population Projected to Reach 9.6 Billion by 2050-UN Report. http://www.un.org/apps/news/story.asp?NewsID=45165\#.Vfw509-qqko

3 K. von Grebmer, J. Bernstein, N. Prasai, S. Yin, and Y. Yohannes. 2015. 2015 Global Hunger Index: Armed Conflict and the Challenge of Hunger. Washington, DC: International Food Policy Research Institute.

4 M. Baranski et al. 2014. Higher Antioxidant and Lower Cadmium Concentrations and Lower Incidence of Pesticide Residues in Organically Grown Crops: A Systematic Literature Review and Meta-Analyses. British Journal of Nutrition. 112. (5 September 2014) pp. 794-811.

5 R. C. Izaurralde and C. C. Cerri. 2002. Organic Matter Management. Encyclopedia of Soil Science. New York: Marcel Dekker. OECD. 2015. Water Use in Agriculture. http://www.oecd.org/agriculture/water-use-in-agriculture.htm.

7 S. Scheierling. 2011. Adapting Soil-Water Management to Climate Change: Insights from a Portfolio Review. Washington, DC: World Bank. http://siteresources.worldbank.org/INTARD/Resources/CSA_WaterManagement_portfolio.pdf

8 United Nations Office for the Coordination of Humanitarian Affairs. 2016. El Niño: Overview of Impact, Projected. New York. Humanitarian Needs and Response. http://reliefweb.int/sites/reliefweb.int/files/resources/OCHA_EINino_Monthly _Report_2Jun2016.pdf (accessed January 2017). 
agriculture sustainable while feeding a growing population should be a concern for all. Everyone with access to soil, starting from one's own backyard, and not just farmers in the rural areas, can start regenerative agriculture. Those without access to land can support by purchasing organic produce of farmers who practice climate-friendly agriculture.

\section{BRIEF EVOLUTION OF AGRICULTURE PRACTICES}

11. Humans depend on agriculture for food and fiber, and agriculture is by far the largest human enterprise. Despite the declining size of the sector in developed economies, the sector still utilized 38\% of global land area and employed about $31 \%$ of the world's population in $2010 .{ }^{9}$

12. Agriculture is closely linked to the rise and fall of civilizations. Agricultural societies developed as man learned to domesticate plants and animals in a markedly different manner from their wild ancestors. Collectable evidence shows that man began farming around 12,000 years ago. One of the earliest practices shown on record was the cultivation of rice in the People's Republic of China (PRC) where it was grown as staple crop. The Sumerians practiced agriculture as we know it today, 7,500 years ago. Their operation included large-scale intensive cultivation of land, monocropping, organized irrigation, and use of a specialized labor force. ${ }^{10}$ By the late 20th century, foraging societies were largely gone." In the last 65 years, the so-called Green Revolution has swept across the globe, with agriculture becoming mechanized. Traditional inputs are replaced by fossil fuel-based inputs.

\section{A. The Green Revolution and Modern Agricultural Practice}

13. The Green Revolution started with disease-resistant high-yielding wheat varieties in the 1940s in Mexico. These varieties were specially designed to increase yields with synthetic fertilizer and agrochemical applications and required stable water supply. This turned the country from a net importer to an exporter of wheat after it was widely adopted in the country. ${ }^{12}$ However, success was short-lived as Mexico began importing basic grains by the end of 1970s. ${ }^{13}$ The Green Revolution had become widespread in the 1960s, but its negative effects became evident 1-2 decades later.

14. Under the Green Revolution, agriculture uses high-yielding varieties and hybrid seeds, farm machineries, irrigation water, fertilizers, and pesticides. ${ }^{14}$ As chemical inputs are fossil fuel-based and machines also use fossil fuels to run, the industrialization of agriculture is energy-intensive with a high carbon footprint. Energy-wise, it takes 10 calories of energy to produce one calorie of food in modern agriculture, as opposed to one calorie of sunlight energy to produce two calories of food in the pre-Green Revolution era. ${ }^{15}$

9 World Bank. http://data.worldbank.org/indicator/SL.AGR.EMPL.ZS/countries/1W?display=graph (accessed September 2015).

10 History of Agriculture. 2015. New World Encyclopedia. http://www.newworldencyclopedia.org/entry/History_of_agriculture

1 Agriculture and the Environment: A Historical Perspective. History of Agriculture Course Materials. United Kingdom: University of Reading. http://www.ecifm.rdg.ac.uk/domcs.htm

12 ThoughtCo. All You Wanted to Know About the Green Revolution. http://geography.about.com/od/ globalproblemsandissues/a/greenrevolution.htm

13 D. Sonnenfeld. 1992. Mexico's “Green Revolution,” 1940-1980: Towards an Environmental History. Environmental History Review. 16 (4). pp. 28-52.

14 Pesticides in this paper refer to both insecticides and herbicides.

15 A.H. Ensminger, M.E Ensminger, J. Konlande and J. Robson. 1993. 2nd ed. Foods and Nutrition Encyclopedia. Florida: CRC Press. 
15. Modern agricultural revolution is credited for production surplus with less human labor. Agricultural production has rapidly increased: between 1960 and 2000, output per hectare tripled for wheat and more than doubled for rice and maize. ${ }^{16}$ In Asia, cereal production doubled between 1970 and 1995 with only a 4\% increase in cultivated land. ${ }^{17}$ The FAO estimates that average per capita food consumption increased by $19 \%$ between 1960 s and $2000 .{ }^{18}$ Without the technologies of the Green Revolution, it was estimated that average caloric availability would have been lower by $11 \%-13 \%$, and food prices would have been higher by $35 \%-65 \% .^{19}$

16. The six basic practices of modern conventional agriculture are described below. ${ }^{20}$ The first four are mostly identified with the technologies of the Green Revolution. Once employed, these practices reinforce each other and productivity is continued only when all practices are employed simultaneously.

(i) Irrigation technologies. This practice allowed water supply to be evenly distributed year round, which allows for multiple cropping in a year. Irrigation water can come from underground wells, dams and distribution canals, and diversion of rivers.

(ii) Genetic manipulation. While cultivation of selected crop plants and animals for specific characteristics has been practiced for centuries, modern agriculture uses hybrid seed, where two or more strains of a crop are combined with genetic engineering. This could involve introducing genetic information of unrelated organisms into another organism.

(iii) Chemical pest control. Pesticides are used to protect crops from organisms that have the potential to reduce yields. Pesticides are either biological or synthetic in origin. Monoculture fields can be protected from organisms that cause diseases in plants with pesticides. Chemical sprays can quickly respond to pest outbreaks.

(iv) Use of synthetic fertilizers. Fertilizers supply the nutrients needed by plants to increase yields. Fertilizer use has increased from 5 to 10 times what it was at the end of World War II (1939-1945).

(v) Monoculture. This practice involves the cultivation of only one crop in a field. Monoculture aims to reduce plant competition for nutrients, space, and energy, and to control unprofitable organisms in the field to maximize profit. Herbicides are often applied to kill unwanted species in monocropping systems.

(vi) Intensive tillage. This practice involves the use of a vast array of tractors and farm implements to loosen the soil. The goals are for seeds to be planted easily, water drainage, and faster root growth. This is used to control weeds and work dead plant matter into the soil.

16 Food and Agriculture Organization of the United Nations (FAO). 2004. The State of Food and Agriculture 2003-2004. Rome.

17 World Bank. 2008. World Development Report 2008: Agriculture for Development. World Bank: Washington, DC. http://siteresources.worldbank.org/INTWDRS/Resources/477365-1327599046334/WDR_00_book.pdf

18 Food and Agriculture Organization of the United Nations (FAO). 2003. World Agriculture: Toward 2015/2030. An FAO Perspective. Rome.

19 R. Evenson. and M. Rosegrant. 2003. The Economic Consequences of Crop Genetic Improvement Programmes. In Evenson and D. Gollin, eds., Crop Variety Improvement and Its Effect on Productivity: The Impact of International Agricultural Research. R. Cambridge, MA: CABI Publishing.

20 S. R. Gliessman. 1998. Agroecology: Ecological Processes in Sustainable Agriculture. Chelsea: Ann Arbor Press. 


\section{B. Issues in the Current Agricultural Practice}

17. Modern agriculture has been credited to have staved off famine particularly in the 1960s, reduced poverty, and decreased land conversion for cultivation. ${ }^{21}$ However, in the 1990s, the negative effects of modern agricultural practices on humans and the environment have become more evident and could not be disregarded.

18. The aforementioned practices reinforce each other in creating soils without living organisms. First, excessive tillage and chemical inputs degrade soil, reducing its organic matter content as well as soil microbe biodiversity. ${ }^{22}$ The deeper the tillage, the more soil carbon is released to the atmosphere as $\mathrm{CO}_{2 .}{ }^{23}$ Deep tillage negatively affects soil biology as it accelerates the breakdown of organic materials that prevent soil from becoming very dense or compacted. This makes it difficult for plants to grow, as roots cannot penetrate the soil to obtain nutrients, water, and structural support. Compacted soil inhibits organisms that recycle nutrients and aerate the soil, and allows water to easily run off the surface and cause erosion. ${ }^{24}$

19. Second, the practice of monocropping is vulnerable to massive pest outbreaks that make for continued and excessive use of chemical sprays. The use of hybrid seeds and genetically engineered crops in monoculture has caused genetic diversity loss and increased risk of substantial crop failure as these seeds do not have the necessary ecological defense mechanisms. Cycles of nutrient, energy, water and wastes are oftentimes open in large-scale agricultural operations, making recycling of agricultural wastes difficult. Moreover, the added impacts on the environment and people of genetically engineered crops, which often contain antibiotics markers, are still largely unknown. ${ }^{25}$

20. Third, modern agriculture is water-intensive and utilizes up to $80 \%$ of fresh surface water, which necessitates irrigation. However, irrigation schemes could expand the habitat of disease vectors thriving in and around water bodies. The practice also degrades soil, making it unable to retain rain water. These runoffs often have chemical fertilizers and agrochemicals that are easily leached out into bodies of water and even underground water supplies. Modern agriculture is not appropriate for rainfed areas where majority of the poor reside and will produce roughly $60 \%-80 \%$ of future food production.

21. Fourth, modern agriculture is dependent on chemical inputs. Chemical fertilizers are designed to increase nutrient uptake of crops to increase yields. However, not all applied fertilizer is recovered by crops, thus ending up as pollutants of surface water, which leads to eutrophication and pollution of surface and ground waters. Overuse of nitrogen fertilizers can cause high nitrate concentration in drinking water, which has been linked to abnormal hemoglobin levels and the consequential blue-baby syndrome in infants. It can also lead to gastric, bladder, and esophageal cancers in adults. Pesticides, which account for about $90 \%$ of pest control in agroecosystems, destroy beneficial natural predators

${ }_{21}$ P. Pingali. 2012. Green Revolution: Impacts, Limits, and the Path Ahead. PNAS. 109 (31). http://www.ncbi.nlm.nih.gov/ pmc/articles/PMC3411969/

22 P. Mozumdera. and R. P. Berrens. 2007. Inorganic Fertilizer Use and Biodiversity Risk: An Empirical Investigation. Ecological Economics. 62 (3-4). pp. 538-43. http://dx.doi.org/ 10.1016/j.ecolecon.2006.07.016

23 L. Overstreet and J. DeJong-Huges. The Importance of Soil Organic Matter in Cropping Systems of the Northern Great Plains. University of Minnesota Extension. http://www.extension.umn.edu/agriculture/tillage/importance-of-soil-organic-matter/

24 R. Pineo and S. 2009. Combating Soil Compaction. College of Agriculture and Natural Resources, University of Delaware. http://extension.udel.edu/blog/tag/excessive-tillage/

25 Friends of the Earth. 2003. Genetically Modified Crops and Food: Briefing. http://www.foe.co.uk/sites/default/files/ downloads/gm_crops_food.pdf 
and parasites of pests. ${ }^{26}$ In humans, apart from the yearly death toll of 220,000 and 750,000 cases of chronic illnesses due to pesticide poisonings alone ${ }^{27}$ exposure to pesticides, herbicides, and fertilizer residues has been linked to the development of neurological disorders, immune suppression, and reduced fertility. ${ }^{28}$ The use of agrochemicals can also pose health problems for primary consumers, such as mosquito larvae or vector snails in wetlands. ${ }^{29}$ Moreover, there is growing epidemiological evidence in the United States on strong temporal correlations between the use of glyphosate, a widely used herbicide, and a multitude of cancers that are reaching epidemic proportions, including breast cancer, pancreatic cancer, kidney cancer, thyroid cancer, liver cancer, bladder cancer, and myeloid leukemia.

22. Global fertilizer use has been trending upward (Table 1). ${ }^{30}$ As salts build up in soil from chemical inputs, soil desertification and erosion increase stress on the soil and the environment. Modern farm systems depend on chemicals for pest management. Hence, larger amounts of sprays are needed as pests become resistant to insecticides, which have heightened concerns on food and water safety. This has become a vicious cycle beleaguering modern food production systems.

Table 1: Global Fertilizer Consumption (kg/ha)

\begin{tabular}{|c|c|}
\hline Year & Fertilizer Consumption of Arable Land \\
\hline 2005 & 115.6 \\
\hline 2009 & 128.9 \\
\hline 2012 & 141.3 \\
\hline
\end{tabular}

Source: World Bank. World Bank Indicators.

https://data.worldbank.org/indicator/AG.CON.FERT.ZS (accessed January 2016).

23. Fifth, modern agriculture is energy-intensive, particularly in the manufacture of its chemical inputs such as nitrogen fertilizer. ${ }^{31}$ Fertilizers and pesticides alone account for $45 \%-55 \%$ of the total energy involved in world crop production. ${ }^{32}$ In the United States, in the 60 years that saw the tripling of crop yields using fossil energy, input consumption increased 40 times. ${ }^{33} \mathrm{FAO}$ estimates that agricultural emissions from crop and livestock production increased by 14\% from 2001 to 2011, and the increase mostly came from developing countries as they expanded total agricultural outputs.

26 D. Pimentel. 2005. Environmental and Economic Costs of the Application of Pesticides Primarily in the United States. Environment. Development and Sustainability. 7. pp. 229-252.

27 Footnote 25.

28 J. A. Patz, U. E. C. Confalonieri, F. P. Amerasinghe, K. B. Chua, P. Daszak, A. D. Hyatt, et al. 2005. Human Health: Ecosystem Regulation of Infectious Diseases. A Report of the Millennium Ecosystem Assessment. Washington, DC: Island Press.

29 P. A. Roger, K. L. Heong, and P. S. Teng. 1991. Biodiversity and Sustainability of Wetland Rice Production-Role and Potential of Microorganisms and Invertebrates. Casafa Rep. 4. pp. 117-36.

30 World Bank. http://data.worldbank.org/indicator/AG.CON.FERT.ZS/countries/1W?display=graph (accessed January 2016).

31 M. Baranski, et. al. 2014. Higher Antioxidant and Lower Cadmium Concentrations and Lower Incidence of Pesticide Residues in Organically Grown Crops: A Systematic Literature Review and Meta-Analyses. British Journal of Nutrition. 112 (5 September 2014). pp. 794-811.

32 Z. R. Helsel, 1987. Energy and Alternatives for Fertilizer and Pesticide Use. In Energy in Farm Production. Ed. R.C. Fluck. Volume 6. Amsterdam: Elsevier.

33 D. Pimentel and W. Dazhong. 1988. Energy Use in the Crop Systems in China. Critical Reviews in Plant Sciences. Volume 7. Issue 1. 


\section{CONVENTIONAL AGRICULTURAL PRACTICES IN THE GREATER MEKONG SUBREGION}

24. The Greater Mekong Subregion (GMS) is composed of Cambodia, the Lao People's Democratic Republic (Lao PDR), Myanmar, Thailand, Viet Nam, and Yunnan and Guangxi Provinces of the PRC. The GMS was formed in 1992. ${ }^{34}$ These economies share the Mekong River Basin and had a combined population of about 271 million in 2010,35 and about 328 million by 2014 (Table 2).

Table 2: Population in the Greater Mekong Subregion, 2014

\begin{tabular}{|c|c|}
\hline Economies & Total Population \\
\hline Cambodia & $15,328,136$ \\
\hline Lao PDR & $6,689,300$ \\
\hline Myanmar & $53,437,159$ \\
\hline Thailand & $67,725,979$ \\
\hline Viet Nam & $90,730,000$ \\
\hline PRC (Guangxi and Yunnan Provinces) & $94,060,000^{\mathrm{a}}$ \\
\hline $\begin{array}{l}\text { Total Population } \\
\text { (with Guangxi and Yunnan Provinces) }\end{array}$ & $327,970,574$ \\
\hline (without Guangxi and Yunnan Provinces) & $(233,910,574)$ \\
\hline \multicolumn{2}{|c|}{$\begin{array}{l}\text { Lao PDR = Lao People's Democratic Republic, PRC = People's Republic of China. } \\
\text { a Figures for Guangxi and Yunnan Provinces are } 2013 \text { population data. } \\
\text { http://www.statista.com/statistics/279013/population-in-china-by-region (accessed January 2016) } \\
\text { Source: World Bank. World Bank Indicators. https://data.worldbank.org/indicator/SP.POP.GROW } \\
\text { (accessed January 2016). }\end{array}$} \\
\hline
\end{tabular}

25. With limited arable lands, farming systems in the region's core agricultural areas are usually the first to intensify production adopting the Green Revolution technologies. The GMS, along with most Asian countries, experienced significant productivity growth in the last 3 decades, with growing needs for water, nutrients, pesticides for crops, and feeds supplemented with hormones and antibiotics for livestock productions.

26. The PRC's yields averaged 6.6 tons per hectare ( $\mathrm{t} / \mathrm{ha}$ ) over a 5-year period, followed by Viet Nam at $5.3 \mathrm{t} / \mathrm{ha}$ (Table 3). In terms of rice exports by volume, Thailand topped the ranking in 2011 , followed by Viet Nam at 7 million tons (Table 4). ${ }^{36}$

34 Asian Development Bank. 2004. The Greater Mekong Subregion: Beyond Borders: Regional Cooperation Strategy and Program (2004-2008). Manila.

35 Food and Agricultural Organization of the United Nations Statistics Division. FAOStat. http://faostat3.fao.org (accessed January 2016).

36 Reuters. 2012. Factbox: World's Top 10 Rice Exporters and Importers. 9 August. http://in.reuters.com/article/2012/08/ 08/thailand-rice-factbox-idINL4E8IJOLI20120808 
Table 3: Productivity Indicators, 2007-2011 (5-year average)

\begin{tabular}{|l|c|c|c|}
\hline Economies & $\begin{array}{c}\text { Annual Paddy Rice } \\
\text { Yields }(\mathrm{t} / \mathrm{ha})\end{array}$ & $\begin{array}{c}\text { Annual Rubber } \\
\text { yields (t/ha) }\end{array}$ & $\begin{array}{c}\text { Annual Hen Egg } \\
\text { Yields (kg/bird) }\end{array}$ \\
\hline Cambodia & 2.8 & 1.07 & 3.1 \\
\hline Lao PDR & 3.7 & - & 5.5 \\
\hline Myanmar & 4.0 & 0.64 & 5.4 \\
\hline Thailand & 3.0 & 1.67 & 7.4 \\
\hline Viet Nam & 5.3 & 1.68 & 4.6 \\
\hline PRC & 6.6 & 1.08 & 9.3 \\
\hline
\end{tabular}

ha $=$ hectare, $\mathrm{kg}=$ kilogram, Lao PDR = Lao People's Democratic Republic, PRC = People's Republic of China, $\mathrm{t}=$ ton.

Source: D. deB. Richter, A. R. Bacon, Z. Brecheisen, and M. L. Mobley. 2015. Soil in the

Anthropocene. IOP Conference Series: Earth and Environmental Science. 25: 012010.

Table 4: World's Top Rice Exporters, 2015 (\$ billion)

\begin{tabular}{|l|c|}
\hline Country and Rank & Amount \\
\hline (2) Thailand & 6.4 \\
\hline (5) Viet Nam & 1.6 \\
\hline (9) Cambodia & 0.37 \\
\hline (11) PRC & 0.24 \\
\hline (19) Myanmar & 0.11 \\
\hline
\end{tabular}

PRC = People's Republic of China

Note: Numbers in parentheses indicate rank of countries among global rice exporters.

Source: World's Top Exports. Rice Exports by Country. www.worldstopexports.com/rice-exports-country/

27. The GMS countries are known for rice cultivation and are among world's top rice exporters as shown in Table 4. Apart from rice, the GMS also practiced intensive cropping systems of fruit, vegetables, and flowers. Land areas under these crops doubled in the past few decades. Thailand diversified its agricultural production with fruits and vegetables, increasing land areas devoted to their cultivation by about 5\% per year, from about 400,000 hectares in 1961 to 1.14 million hectares in 2002 (footnote 17).

\section{A. Issues of Modern Agriculture in the Greater Mekong Subregion}

28. The main problem of modern agriculture in the GMS is associated with the practice of intensive cropping systems, which have brought abuse and overuse of fertilizers and pesticides, and soil erosion. ${ }^{37}$ Ample evidence on the negative effects of intensification in crop systems exists in the literature. Some of these are presented below. ${ }^{38}$

37 B. Rerkasem. 2005. Transforming Subsistence Cropping in Asia. Plant Production Science. 8(3). pp. $275-87$. http://dx.doi.org/10.1626/pps.8.275

38 D. deB. Richter, A. R. Bacon, Z. Brecheisen, and M. L. Mobley. 2015. Soil in the Anthropocene. IOP Conference Series: Earth and Environmental Science. 25: 012010. 


\section{Excessive Inorganic Fertilizer Use}

29. A study in 2003 estimated the nitrate concentration from fertilizer runoff at 3.5 grams per liter $(\mathrm{g} / \mathrm{l})$ at the mouth of the Mekong and at $5.5 \mathrm{~g} / \mathrm{l}$ at the mouth of the Chao Phraya River in 2000.39 For these waters to be used for drinking, contamination level of nitrate should be reduced to 10 milligram per liter or 10 parts per million based on standards of the United States Environmental Protection Agency for public water systems. ${ }^{40}$ As shown in Table 5, the global increase in nitrogen fertilizer production has been greatly increased in the last decade. Much of the global increase in fertilizer production of 31\% in from 2002 to 2013 appeared to be driven by high demands in East Asia, which increased by $57 \%$ over the same period.

\section{Table 5: Production of Ammonia ('000 tons)}

\begin{tabular}{|l|c|c|}
\hline Year & Total World & East Asia \\
\hline 2002 & 106,806 & 34,661 \\
\hline 2013 & 139,945 & 54,405 \\
\hline
\end{tabular}

Source: International Fertilizer Industry Association.

\section{Excessive Chemical Pesticide Use}

30. For 1997-2007, nearly 1,100 new types of pesticides were registered in Viet Nam, ${ }^{41}$ and pesticide use by weight grew at an annual average of $7.6 \%$ between 1990 and 2003 . Banned compounds, due to their hazardous effects on human health, are still found in pesticide formulations owing to weak government enforcement. ${ }^{42}$ In another study that measured farmers' exposure to an insecticide that can hamper proper functioning of the nervous system, it was found that pesticide uptake exceeded international safety levels and likely caused adverse health effects. ${ }^{43}$ Moreover, reliance on surface water as a source of drinking water may have already caused people to have the symptom of long-term consumption of local pesticide residues.

31. In most GMS countries, glyphosate, the world's leading herbicide, is the active ingredient in a pesticide known as Roundup, which is extensively used in maize, cassava, rubber, and tobacco production, despite the fact that the World Health Organization has indicated the herbicide as a likely carcinogen. In 2009, Cambodia banned 116 chemical pesticides but glyphosate has been on the "safe" list. Glyphosate is legal and easily available in the local markets of the PRC, Thailand, and Viet Nam.

39 Y. K. S. Suga and T. Oki. 2003. Estimation of the Amount of Nitrate Originated from Nitrogenous Fertilizer in a Global River Model. Bangkok: IWA Publishing.

40 United States Environmental Protection Agency. Basic Information about Nitrate in Drinking Water. http://water.epa.gov/drink/contaminants/basicinformation/nitrate.cfm

$41 \quad$ P. V. Hoi, A. Mol, P. Oosterveer, and P. J. van den Brink. 2009. Pesticide Distribution and Use in Vegetable Production in the Red River Delta of Vietnam. Renewable Agricultural and Food Systems. 24. pp. 174-85. http://dx.doi.org/ 10.1017/S1742170509002567

42 T. D. Khanh, T. D. Xuan, D. V. Chin, I. M. Chung, E. A. Abdelghany, and S. Tawata. 2006. Current Status of Biological Control of Paddy Weeds in Vietnam. Weed Biology and Management. 6(1). pp. 1-9.

43 D. T. Phung, D. Connell, G. Miller, M. Hodge, R. Patel, R. Cheng, et al. 2012. Biological Monitoring of Chlorpyrifos Exposure to Rice Farmers in Vietnam. Chemosphere. 87 (4). 294-300. http://dx.doi.org/10.1016/j.chemosphere.2011.11.075 


\section{Greenhouse Gas Emissions from Intensive Agriculture}

32. Being the staple food in the GMS, rice cultivation is the dominant agricultural activity in the GMS. However, rice production is also a major source of GHG, emitting about 500-800 million tons of $\mathrm{CO}_{2}$ equivalent per year, or roughly $10 \%$ of total agricultural $\mathrm{GHG}$ emissions. ${ }^{44} \mathrm{GHG}$ emissions in the GMS has risen, with the PRC leading the rise in absolute terms, while Viet Nam increased its emissions eightfold over 20 years (Table 6). In Myanmar, the relatively high GHG emissions in 1992 were mainly due to land use change and in forestry principally from deforestation, shifting cultivation, and land clearance, which have further increased in 2 decades. ${ }^{45}$

\section{Table 6: Greenhouse Gas Emissions in the Greater Mekong Subregion Including Land Use Change and Forestry $(\mathrm{mtCO} 2 \mathrm{e})$}

\begin{tabular}{|l|c|c|}
\hline Country & 1992 & \multicolumn{1}{|c|}{2012} \\
\hline Cambodia & 42.60 & 49.12 \\
\hline Lao PDR & 27.96 & 36.28 \\
\hline Myanmar & 166.95 & 184.71 \\
\hline Thailand & 187.75 & 375.71 \\
\hline Viet Nam & 28.36 & 251.18 \\
\hline PRC & $3,306.65$ & $10,684.29$ \\
\hline
\end{tabular}

$\mathrm{mtCO} \mathrm{C}_{2}=$ metric tons carbon dioxide equivalent. Source: World Resources Institute.

\section{Irrigation Systems}

33. Roughly only $5 \%$ of global agricultural land is irrigated and the Asian region has the most countries dependent irrigation. ${ }^{46}$ Irrigation structures and diseases are closed linked. Like other regions of the world where intensive agriculture utilize $70 \%-80 \%$ of fresh water, GMS countries are under pressure to increase efficient use of water in agriculture.

\section{REINVENTING AGRICULTURE}

34. With increased awareness on the negative externalities and unsustainable practices associated with intensive agriculture, the world is in search of alternative agriculture systems that are more sustainable, climate-friendly, and health-restoring. Among the approaches is the strategy to restore soil heath or soil quality, which includes chemical, physical and biological characteristics of soil. Soil physical properties include soil color, texture, structure, soil moisture content, horizonation (discrete layers that make up soil profile), and bulk density, which in turn are affected by the varying proportions of minerals,

44 T. K. Adhya, B. Linquist, T. Searchinger, R. Wassmann, and X. Y. Yan. 2014. Wetting and Drying: Reducing Greenhouse Gas Emissions and Saving Water from Rice Production. Working Paper. Installment 8 of "Creating a Sustainable Food Future." Washington, DC: World Resources Institute.

45 Grantham Research Institute for Climate Change and the Environment. 2017. The London School of Economics and Political Science. http://www.Ise.ac.uk/Granthamlnstitute/legislation/countries/myanmar/

46 H. P. Galbraith, P. Amerasinghe and A. Huber-Lee. 2005. The Effects of Agricultural Irrigation on Wetland Ecosystems in Developing Countries: A Literature Review. CA Discussion Paper. 1. Colombo: Comprehensive Assessment Secretariat. http://www.iwmi.cgiar.org/assessment/files_new/publications/Discussion\%20Paper/CADiscussionPaper1.pdf 
soil organic matter (SOM), water, and air in the soil. ${ }^{47}$ Chemical interactions in the soil are determined by two properties: cation exchange capacity and soil reaction ( $\mathrm{pH}$ level). Clay soils usually have a greater exchange capacity. ${ }^{48}$ However, knowledge on soil biology or soil health has traditionally been inadequate, which has limited the understanding of its dynamic properties and potentialities. ${ }^{49}$ Research in the last century has mainly focused on chemical and physical characteristics, and only recently did it expand into soil biological properties.

\section{A. Soil Biology and the Soil Food Web}

35. What is now understood is that plants and soil relationships are more complex than originally thought and nutrients needed by plants cannot be simply supplied by chemical applications. Plant growth requirements are not only nitrogen, phosphorous, and potassium, but include a host of minerals needed at variable amounts in the course of their growth. Myriad organisms working around the plant roots allow precise amounts of various nutrients to be supplied when exactly needed. This is the importance of soil biology..$^{50}$

36. The soil environment is teeming with life, from microscopic to visible organisms, and is one of the most diverse ecosystems on earth. A cup of undisturbed native soil typically has 200 billion bacteria and 100,000 meters of fungi. ${ }^{51}$ This community of complex sets of beneficial organisms living all or part of their lives in the soil and around the plant roots that helps plants obtain nutrients is the soil food web. The food web describes the many potential pathways of the conversions of energy and nutrients, as an organism is eaten by another. The exact composition of organisms in a soil web depends on various factors, such as soil type, organic matter, temperature, climate, and land management practices. As organisms decompose complex materials, or consume other organisms, nutrients are converted into forms that can be used by plants and other soil organisms. The nutrition of plants depends on the soil food web..$^{2}$

37. The soil food web supplies plants with needed nutrients; this function considerably depends on the diversity of life in the soil. Below is a discussion on the soil's biology (fauna, flora, and microorganisms), which contribute to the soil's development, structure, and fertility. ${ }^{53}$

\section{Soil Flora}

38. Plants supply SOM via shoot and root residue. Root channels are created when roots decompose, allowing soil and air movement that aids in structure and porosity. Roots can stabilize soil through aggregation, and intact root systems can decrease soil loss. The narrow area surrounding the plant roots has sloughed-off root cells and secreted chemicals (i.e., sugars, organic acids) that provide organisms with food.

47 A, C. Jones McCauley and J. Jacobsen. 2005. Basic Soil Properties. Soil and Water Management Module 1. 4481-1. January. http://landresources.montana.edu/swm/documents/Final_proof_SW1.pdf

48 N. C. Brady. 1990. The Nature and Properties of Soil. New York: Macmillan Publishing Company.

49 S. Sherwood and N. Uphoff. 2000. Soil Health: Research, Practice and Policy for a More Regenerative Agriculture. Applied Soil Ecology. 15. pp. 85-97.

50 E. Ingham. 1998. Soil Organism and Their Role in Healthy Turf. TurfGrass Trends. 7 (8 August).

51 C. Moravec, A. Card, C. Wilson, and J. Reeder. 2015. The Living Soil. CMG Garden Notes. No. 212. Colorado State University Extension. http://www.ext.colostate.edu/mg/gardennotes/212.pdf

52 Natural Resources Conservation Service Soils. Soil Biology Primer. 2015. http://www.nrcs.usda.gov/wps/portal/nrcs/ main/soils/health/biology/

53 A. C. Jones McCauley and J. Jacobsen. 2005. Basic Soil Properties. Soil and Water Management Module 1. 4481-1. January. http://landresources.montana.edu/swm/documents/Final_proof_SW1.pdf 


\section{Soil Fauna}

39. Soil fauna includes earthworms, insects, nematodes, arthropods, and rodents, which initiate the breakdown of dead plant and animal material, ingesting and processing large amounts of soil, burrowing "biopores" for water and air movement, mixing soil layers, increasing aggregation, and excreting nutrientrich secretions.

\section{Soil Microorganisms}

40. Soil microbes are invisible to the naked eye. They include bacteria, protozoa, algae, and fungi. Soil microbes are important in SOM decomposition and nutrient transformation. Some bacteria, such as Rhizobia, fix nitrogen inside legume roots. Protozoa (e.g., amoebas, ciliates, flagellates), which are mobile organisms, feed on other microbes and SOM, while fungi are a diverse group of microbes with usually thin, thread-like extensions that physically bind soil particles. Bacteria usually dominate in agricultural and grassland soils, and fungi are more prevalent in forest and acid soils. ${ }^{54}$ An important interacting relationship between plants and microorganism is mycorrhizae, which fungi infect and live in or on a plant root. The fungus depends on the plant for energy and the plant benefits from the fungus in terms of aiding nutrient uptake and improving plant growing conditions.

\section{B. Regenerative Agriculture, Soil Biology, and Carbon Sequestration}

41. The practice of agriculture that aims to work with the natural processes and biological cycles in soils, crops, and livestock to build up soil fertility and enhance SOM, rather than use fertilizers and agrochemicals, is known as regenerative agriculture. ${ }^{55}$ Regenerative agriculture enhances life in soils, creating a community of organisms high in biodiversity, which process and decompose plant and animal matter. Data from the Rodale Institute indicate that regenerative and organic practices can increase soil carbon. Their long-term farm trial shows a $30 \%$ increase in soil carbon over 27 years in organically farmed soils, while chemically formed soils did not increase soil carbon. The microbial life in soil stabilizes soil carbon and sequesters atmospheric carbon into the soil. In a study on the relationship between soil carbon sequestration, plant nutrients, and biological activities in organic and conventional tea farming, it was found that concentrations of soil organic carbon and microbial biomass carbon were higher in soils with longer periods under organic management. This suggests that organic farming could promote soil carbon sequestration and microbial biomass size and activities. ${ }^{56}$

\section{Biodiversity in Soil Organisms and Its Benefits}

42. The biodiversity of the organisms in the soil perform vital ecosystem services that include nutrient cycling, aiding in soil formation and regulation of atmospheric composition and climate, improving water quantity and quality, as well as maintaining soil productivity. More biodiverse soil

54 A. J. Tugel and A. M. Lewandowski, eds.1999. Soil Biology Primer. NRCS. lowa: Soil Quality Institute.

55 Regenerative agriculture is a version of organic agriculture designed to rebuild soil health or regenerate unhealthy soil. Organic agriculture is a holistic production management system that promotes and enhances agro-ecosystem health, including biodiversity, biological cycles, and soil biological activity. It emphasizes the use of management practices over offfarm inputs, taking into account that regional conditions require locally adapted systems. This is accomplished by using, where possible, agronomic, biological, and mechanical methods, as opposed to synthetic materials, to fulfill any specific function within the system (FAO/WHO Codex Alimentarius Commission 1999).

56 W. Y. Han, R. Z. Shi, J. M. Xu, L. F. Ma, and K. Wei. 2013. Soil Carbon Sequestration, Plant Nutrients and Biological Activities Affected by Organic Farming System in Tea (Camellia sinensis (L.) O. Kuntze) Fields. Soil Science and Plant Nutrition. 59 (5 October). pp. 727-739. 
environments have more kinds of predators that reduce the chance of some species to dominate, which in turn reduces the risks of diseases in plants and humans, and control growth of pests. ${ }^{57}$ Hence, agrochemical inputs are not needed in soils with high biodiversity. Soil organisms also reduce environmental pollution through bioremediation, and soil's genetic resources have been tapped to develop antibiotics and other drugs. The first successful antibiotic (Penicillin) was isolated from the soil fungus Penicillium, which was discovered in 1928. The drug prevented deaths from infections in the Second World War and opened the door for new miracle drugs that save millions of lives. ${ }^{58}$ The benefits of biodiversity of organisms in soils are discussed below. ${ }^{59}$

\section{Soil Structure, Soil Organic Matter, and Soil Fertility}

43. Soil structure refers to the arrangement of soil separates into units called soil aggregates and greatly affects water and air movement in the soil, biological activity, root growth, and seedling emergence. Microbial activity that aids in the decay of SOM contributes to formation of aggregates. SOM is an important building block for soil structure, contributing to soil aeration, and enabling soils to absorb water and retain nutrients. Every year, soil organisms process 25,000 kilograms of organic matter. The quantity of water stored in soil and available for plants increases as SOM increases. ${ }^{60} \mathrm{An}$ increase of one percentage point in SOM helps soil hold 20,000 gallons more water per acre (0.4 hectare). ${ }^{61}$

44. The decomposition of SOM by soil organisms releases nutrients in forms usable by plants and other organisms. The residual SOM forms humus, which is the dark organic material in soils and serves as the main driver of soil quality and fertility. SOM as humus is produced by the diversity of life that exists in soils.

\section{Regulation of Carbon Flux and Climate Control}

45. Soil has about 2,500 billion tons of carbon to 1 meter depth. Carbon in soil is held by decomposing organic matter in pore spaces between soil particles, and contained in living soil organisms. Soil organisms increase soil carbon through the decomposition of dead biomass, while their respiration releases $\mathrm{CO}_{2}$ to the atmosphere. Carbon is also released as methane when soils are flooded or clogged with water. Land-use change, through the conversion of forests and grasslands to agricultural lands, is responsible for the largest carbon losses from soils.

\section{Regulation of the Water Cycle}

46. Visible organisms, such as earthworms, ants, termites and small animals, affect the infiltration and distribution of water in the soil, by creating soil aggregates and pore spaces. Reducing earthworm populations can reduce the water infiltration rate significantly by up to $93 \%$. Biodiversity in the soil contributes to water purification, nutrient removal, and to the biodegradation of contaminants and of

57 European Commission on Environment. Soil Biodiversity-The Factory of Life. http://ec.europa.eu/environment/archives/ soil/pdf/soil_biodiversity_leaflet_en.pdf

58 Medical Discoveries. Penicillin. http://www.discoveriesinmedicine.com/Ni-Ra/Penicillin.html

59 See A. Turbé, A. De Toni, P. Benito, P. Lavelle, P. Lavelle, N. Ruiz, W. H. van der Putten, E. Labouze, and S. Mudgal. 2010. Soil Biodiversity: Functions, Threats and Tools for Policy Makers. Paris: Bio Intelligence Service. http://ec.europa.eu/ environment/archives/soil/pdf/biodiversity_report.pdf

60 B. D. Hudson. 1994. Soil Organic Matter and Available Water Capacity. Journal of Soil and Water Conservation. 49(2). pp. 89-194.

61 E. Goode. 2015. Farmers Put Down the Plow for More Productive Soil. New York Times. 9 March. This is according to Claire O' Connor from the Natural Resource Defense Council. http://www.nytimes.com/2015/03/10/science/farmers-put-downthe-plow-for-more-productive-soil.html?_r=0 
pathogenic microbes. Plants are also involved in water cycling through transpiration, whereby water is released to the atmosphere from soil through plant leaves. ${ }^{62}$ The lack of soil biodiversity will reduce the quality and quantity of ground and surface waters, and nutrients and pollutants may no longer be degraded or neutralized. Surface runoff will increase, increasing risks of erosion and landslides in mountain areas, and of flooding and excessive sedimentation in lowland areas. Each of these losses can result in substantial costs to the economy.

\section{Decontamination and Bioremediation}

47. Microorganisms play a key role in waste management by accumulating pollutants in their bodies, degrading pollutants into smaller, nontoxic molecules, or modifying those pollutants into useful molecules. Plants can also be used in mitigating pollutant concentrations in contaminated soils, which process is indirectly mediated by soil organisms. The loss of soil biodiversity would reduce the availability of microorganisms to render this ecosystem service.

\section{Pest Control}

48. High soil biodiversity is also high in natural pest control potential, as it enables a higher probability of hosting a natural enemy of the pests. Pests serve ecosystems in regulating biodiversity itself. Soil-borne pathogens and herbivores control plant abundance, which enhances plant diversity. The loss of pathogenic and root-feeding soil organisms damages plant diversity and increases risks of exotic plant invasions. Changes in vegetation also influence aboveground biodiversity that could cause loss of biodiversity in entire natural ecosystems.

\section{Human Health}

49. The high biodiversity in soil organisms has been an important source of chemical and genetic resources for new drugs such the antibiotic drug penicillin mentioned above. However, antibiotic resistance develops fast and the high biodiversity in soil is needed to provide sources for new antibiotic compounds. When soil biodiversity is disturbed, in some instances, it releases soil-borne infectious disease with negative impacts to human health. Soil microbes are also used in removing soil contamination of heavy metals such as arsenic and lead, which are toxic to human health. ${ }^{63}$ Moreover, some soil microbes act as an extended root system of plants that can increase uptake of nutrients improving plant health, which in turn benefits consumers of these plants and their produce. ${ }^{64}$

\section{Evidence on Benefits of Healthy Soil}

50. While soil chemistry and physical properties have been amply studied, studies supporting the benefits of healthy soil biology have only been increasing of late. Table 7 shows how the presence of more microorganisms in total biomass increases productivity. Animals gained more weight when fed with biomass grown in soil with more microorganisms, and crop yields are also higher. ${ }^{65}$

62 United States Geological Service. Evapotranspiration: The Water Cycle. http://water.usgs.gov/edu/ watercycleevapotranspiration.html

63 M. S. Akhtar, B. Chali, and T. Azam. 2013. Bioremediation of Arsenic and Lead by Plants and Microbes from Contaminated Soil. Research in Plant Sciences. 1 (3). pp. 68-73. DOI: 10.12691/plant-1-3-4.

64 P. Antunes et al. 2012. Linking Soil Biodiversity and Human Health: Do Arbuscular Mycorrhizal Fungi Contribute to Food Nutrition. In D. Wall, ed., Soil Ecology and Ecosystem Services. United Kingdom: Oxford University Press.

65 E. Ingham and M. Slaughter. 2004. The Soil Food Web: Soil and Composts as Living Ecosystems. Paper presented at the International Conference on Soil and Compost Eco-biology. 15-17 September. Leon, Spain. 
Table 7: Assessment of Ecosystem Productivity

\begin{tabular}{|l|c|c|}
\hline & \multicolumn{2}{|c|}{$\begin{array}{c}\text { Total Biomass } \\
(\mu \mathrm{g} / \mathrm{g} \text { dry weight) }\end{array}$} \\
\hline & Bacteria & Fungi \\
\hline Pasture & & \\
\hline 2 lbs weight gain/animal/day & 675 & 830 \\
\hline $1 \mathrm{lb}$ weight gain/animal/day & 230 & 50 \\
\hline Agricultural field & & \\
\hline 180 bushel yield & 450 & 400 \\
\hline 100 bushel yield & 210 & 75 \\
\hline
\end{tabular}

Note: 1 microgram per gram $=\mu \mathrm{g} / \mathrm{g}, \mathrm{lb}=$ pound or 0.45 kilogram.

Source: E. Ingham and M. Slaughter. 2004. The Soil Food Web: Soil and Composts as Living Ecosystems. Paper presented at the International Conference on Soil and Compost Eco-biology. 15-17 September. Leon, Spain.

\section{E. Fostering Soil Biology toward Healthy Soil}

51. To promote healthy soil, certain factors are necessary. The biological activity in the soil is mainly affected by limiting factors: humus and SOM, primarily nitrogen content. Adequate oxygen levels, nearneutral $\mathrm{pH}$, temperatures between $29^{\circ} \mathrm{C}$ and $35^{\circ} \mathrm{C}$, and $50 \%-60 \%$ moisture are the major physical properties of the soil that also promote biological activity. ${ }^{66}$ Outside these ranges, biological activity decreases except for a few organisms that have adapted to extreme environmental conditions. To foster healthy soils, the practices of conventional agriculture mentioned above have to be reversed.

\section{F. Farming Practices that Improve Soil Health in the Greater Mekong Subregion and the World}

52. Soil conservation farming and organic agriculture practices enhance biodiversity of soil organisms and stabilize soil aggregates that are essential in creating a healthy food web in soils surrounding the plant roots. These practices reinforce each other to build healthy soils. The end goal of managing soil health is to produce healthy crops while enhancing productive bases. This means farming practices should ensure the uptake of a good balance of nutrients for the crop and ensure agricultural sustainability.

\section{System of Rice Intensification}

53. In GMS, rice is the main crop produced. The GMS has some of the world's top rice exporting countries. Rice production, however, is a major source of methane, a greenhouse gas. Introducing changes in rice cultivation techniques such as minimizing the practice of continuous flooding of rice paddies, which induces the anaerobic condition in soil, can reduce methane emissions. The first three in the list below are soil friendly farming practices found in the GMS.

54. One methodology is called system of rice intensification (SRI). ${ }^{67} \mathrm{SRI}$ is a climate-smart, agroecological methodology to increase rice productivity, and more recently, other crops by changing the management of plants, soil, water, and nutrients. SRI is based on four main principles that interact with each other: (i) early, quick, and healthy plant establishment; (ii) reduced plant density; (iii)

66 N. Brady and R. Weil. 2002. The Nature and Properties of Soil. New Jersey: Prentice Hall.

$67 \mathrm{SRI}$ is also known more generally as alternative wetting and drying (AWD) in rice growing. 
improved soil conditions through enrichment with organic matter; and (iv) reduced and controlled water application. ${ }^{68}$ Unlike conventional rice cultivation method, irrigation in SRI is performed by alternate wetting and drying, and weeding is done manually, both of which can aerate the soil. ${ }^{69}$

55. The benefits of SRI are becoming known in the GMS. In Viet Nam, 7.7 million hectares of agricultural land are devoted to rice production in 2012, and SRI has been increasingly adopted mostly by women farmers on about 300,000 hectares in 2012. Raising profits with increasing fertilizer costs and water insufficiency problems has made SRI an alternative method to rice farmers. ${ }^{70}$ In Thailand, water problems, such as saline intrusion into agricultural lands and insufficient scope of irrigation system, as well as climate change concerns, have increased interest in SRI. Experiments on SRI conducted in selected 5 provinces in Cambodia and Thailand revealed that average paddy yield could increase up to 6.41 tons per hectare, up from the average baseline yield in the region of 3.14 tons per hectare for the same farmers and same locales. The benefits are even greater for rainfed areas. ${ }^{71}$ In the Lao PDR, experiments on SRI started in 1996, with yields ranging from 1.3 to 9 tons per hectare. The government and various nongovernment organizations (NGOs) are also involved in propagating techniques that work best in specific environments. ${ }^{72}$

\section{Integrated Farming System}

56. Integrated farming system or integrated animal-fish-mixed cropping system combines one or more animals and is common in Asia given the preponderance of small-sized family farms. While it is mostly economics that drive farmers to integrated farming, the environment also benefits as wastes are recycled and chemical usage is minimal or none at all. Integrated farming either combines crops with cattle, fish, or poultry. In Asia, integrated farming is traditionally done with rice and fish. This reduces the cost of rice cultivation through the removal of weeds, insects, and pests that are consumed by the fish; increased fertilization of the rice plants, and increased production of both rice and fish. ${ }^{73}$

\section{Permaculture}

57. Permaculture is another farming approach suitable to the small-sized family farms that dominate the Asian agricultural landscape, some documentation of which has been done in Indonesia, Malaysia, and Thailand. ${ }^{74}$ The word was coined by Bill Mollison and David Holmgren in the mid-1970s

to describe an integrated, evolving system of perennial or self-perpetuating plant and animal species

68 Cornell University, College of Agriculture and Life Sciences. http://sri.cals.cornell.edu/aboutsri/methods/index.html

69 P. Fazli and H. Che Man. 2014. Comparison of Methane Emission from Conventional and Modified Paddy Cultivation in Malaysia. Agriculture and Agricultural Science Procedia. 2. pp. 272-279.

70 Ministry of Agriculture and Rural Development, Plan Protection Department. 2013. Background paper presented at the System of Rice Intensification Lower Mekong River Basin (SRI LMB) Project, Inception and Planning Workshop. 9-12 April 2013, Asian Institute of Technology, Thailand. http://www.sri-Imb.ait.asia/country/doc/background-vietnam.pdf

71 A. Mishra, P. Kumar, and J.W. Ketelaar. 2016. Improving Rice-Based Rainfed Production Systems in Southeast Asia for Contributing towards Food Security and Rural Development through Sustainable Crop Production Intensification. AlMS Agriculture and Food. 1 (2). pp. 102-123. http://www.aimspress.com/article/10.3934/agrfood.2016.2.102/fulltext.html

72 National Agriculture and Forestry Extension Service. 2013. Background paper presented at the System of Rice Intensification Lower Mekong River Basin (SRI LMB) Project, Inception and Planning Workshop. 9-12 April 2013. Asian Institute of Technology, Thailand. http://www.sri-Imb.ait.asia/country/doc/background-lao-pdr.pdf

73 C. Devendra. Integrated Animal-Fish-Mixed Cropping Systems. In Integrated Livestock-Fish Production Systems. Proceedings of the FAO/IPT Workshop on Integrated Livestock-Fish Production Systems. 16-20 December 1991. Institute of Advanced Studies, University of Malaya, Kuala Lumpur. http://www.fao.org/docrep/004/ac155E/AC155E10.htm

74 M. Domiguez. 2011. Permaculture in Southeast Asia: What is It, Who's Doing It \& How Does It Help? https://latitudes.nu/permaculture-in-southeast-asia-what-it-is-who\%E2\%80\%99s-doing-it-how-does-it-help/ 
useful to man. ${ }^{75}$ Permaculture is based on agroecology, an alternative farming approach that mimics natural ecosystems to produce more food using fewer resources.

58. Other farming practices that benefit the soil are listed below. It is noteworthy that they complement each other in enhancing biodiversity of soil organisms, particularly the beneficial ones, such as the mycorrhizal fungi.

\section{No-till Farming}

59. Tillage is the plowing of land to control weeds and pests and to prepare land for seeding. The less the soil is disturbed, the more organic matter, which stores carbon, is retained. No-till farming sequesters carbon and mitigates climate change. ${ }^{76}$ Tillage also affects populations of microorganisms. Short-term bacteria, typically pests, increase with tillage. The converse is true for fungal biomass. Less tillage preserves fungal hyphal networks that help in soil aggregates and increase SOM levels. ${ }^{77}$ Earthworm populations also tend to increase in soil with minimal disturbances, ${ }^{78}$ which helps in soil structure. As residue is left on the soil's surface, this protects soil from water and air erosion. No-till farming has gained popularity in the last 2 decades and is now practiced in over 110 million hectares worldwide, which shows its adaptability to climates, soils, and cropping conditions. ${ }^{79}$ However, it is still limited in Asia and Africa which may be due to (i) costly no-till equipment for mechanized farms, (ii) issues on land tenure, (iii) harsh climate conditions, (iv) knowledge gap, and (v) lack of crop residue mulch. $^{80}$

60. According to Gabe Brown (a renowned no-till farmer), no-till allows farmers to take advantage of the natural processes that happen in the soil, such as the symbiotic relationship of arbuscular mycorrhizal fungi (AMF) with plant roots. AMF penetrates the cells of roots and extends the root network system of plants so plants can store water and nutrients in a bigger area. No-tillage enhances $\mathrm{AMF}$ and protects host plants from pathogens in the soil by preventing them from entering the roots, which decreases and eventually removes inputs of pesticide, fungicides, and herbicides. AMF also builds soil aggregates and improves soil stability with its release of a sticky substance called glomalin (the more large aggregates than small ones, the healthier the soil). AMF also builds soil carbon, improves water efficiency, and increases the efficiency of nitrogen, phosphorus, and sulfur. Practices that increase AMF are the very same practices that enhance soil's biodiversity. ${ }^{81}$ Benefits of mycorrhizae associations include increasing plant-water relations and reducing severity of some plant diseases, ${ }^{82}$ improving soil aggregate stability due to the binding actions of hyphae and glomalin, a mycorrhizal secreted chemical. ${ }^{83}$

75 B. Mollison and D. Holmgren.1978. Permaculture One, 5th ed. Tasmania: Tagari Publications.

76 J. Horowitz, R. Ebel, and K. Ueda. 2010. No-till Farming is a Growing Practice. Economic Information Bulletin. No. 70. United States Department of Agriculture Economic Research Service.. http://www.ers.usda.gov/media/135329/eib70.pdf

77 S. D. Frey, E. T. Elliott, and K. Paustian. 1999. Bacterial and Fungal Abundance and Biomass in Conventional and No-tillage Agroecosystems along Two Climatic Gradients. Soil Biology and Biochemistry. 31. pp. 573-585.

78 O. Olfert, G. D. Johnson, S. A. Brandt, and A. G. Thomas. 2002. Use of Arthropod Diversity and Abundance to Evaluate Cropping Systems. Agronomy Journal. 94. pp. 210-216.

79 R. Derpsch, T. Friedrich, A. Kassam, and H. W. Li. 2010. Current Status of Adoption of No-till Farming in the World and Some of Its Main Benefits. International Journal of Agriculture and Biological Engineering. 3 (1).

$80 \mathrm{H}$. Blanco and R. Lal. 2008. Principles of Soil Conservation and Management. Netherlands: Springer International Publishing.

81 G. Brown. 2014. 5 Keys to Healthy Soil. Idaho Center for Sustainable Agriculture. https://www.youtube.com/ watch?v=9yPjoh9YJMk

82 S. E. Smith and D. J. Read. 1998. Mycorrhizal Symbiosis. Plant Growth Regulation. 25 (1).

83 K. A. Nichols, S. F. Wright, M. A. Liebig, and J. L. Pikul Jr. 2004. Functional Significance of Glomalin to Soil Fertility. In Proceedings from the Great Plains Soil Fertility Conference. 2-4 March. Denver, Colorado. 
Mycorrhizal populations are maintained and enhanced by increasing SOM content, reducing soil disturbances, and eliminating long fallow periods.

\section{Chemical-free Farming}

61. Agro-chemicals, e.g., pesticides, herbicides, fungicides, and synthetic fertilizers harm both pests and beneficial soil organisms. For every target pest killed by pesticide, thousands of beneficial or harmless organisms are also killed in the process. As pathogens and pests have short life spans, and reproduce and adapt rapidly to adverse environments, offspring that has become resistant to agrochemical inputs survives. Hence, the application of chemical inputs is only continued as one chemical input is changed to another to combat resistant pests and plant diseases. Conversely, beneficial organisms have long and complex life cycles and are good at competing with other organisms. Chemical-free farming allows beneficial organisms to perform their ecosystem services of naturally inhibiting, outcompeting, and consuming pests and pathogens. ${ }^{84}$ Chemical-free farming is a challenge in the region. With growing populations and economies, Asian countries increased food production by increasing yields through greater use of chemical fertilizer. Fertilizer consumption per hectare of arable land in Asia increased from 20 kilograms to 145 kilograms from 1969 to $1995 .{ }^{85}$ Nevertheless, negative externalities of agrochemicals to health, environment, and climate change are calling for this trend to reverse.

\section{Cover Crops}

62. These are seeded into agricultural fields, either within or outside of the regular growing season to improve or maintain ecosystem quality. Cover $\mathrm{crops}^{86}$ can be monoculture, polyculture, or mixtures of various kinds of plants seeded with the main crop. The choice of cover crops is affected by the temperature and rainfall of the region, ${ }^{87}$ as well as the type of soil and nutrient needs of the main crop as certain cover crops concentrate specific nutrients in their tissues. Cover crops are often used with notill method and are part of planned rotation. The benefits of living plant cover or living mulch include soil erosion protection, reduced nutrient leaching, carbon sequestration, weed suppression, minimize soil compaction, and integrated pest management. Cover crops regulate temperatures by preventing moisture loss and enhancing water infiltration in soil, which are beneficial during hot and cold seasons. ${ }^{88}$ Cover crops include grasses, legumes, and forbs for seasonal cover and other conservation purposes. ${ }^{89}$

\section{Mulching and Mulch Tillage}

63. Mulching is applying plant residue or other suitable materials to the soil surface. Mulch is material such as rice straw or leaves or food waste that is used to cover soil to regulate heat and compensate for loss of residue due to tillage. Residue is left on the surface of the soil, making it less

84 E. Ingham. 1998. Soil Organism and Their Role in Healthy Turf. TurfGrass Trends. 7 (8 August).

85 M. Hossain and V. P. Singh. 2000. Fertilizer Use in Asian Agriculture: Implications for Sustaining Food Security and the Environment. Nutrient Cycling in Agroecosystems. 57. pp. 155-169.

86 A cover crop is any living ground cover that is planted into or after a cash crop and then commonly destroyed before the next crop is planted. N. L. Hartwig and H. U. Ammon 2002. Cover Crops and Living Mulches. Weed Science. 50 (6). pp. 688-699.

87 J. Hoorman. 2009. Using Cover Crops to Improve Soil and Water Quality. Fact Sheet: Agriculture and Natural Resource. Ohio State University Extension. http://www.ctic.org/media/pdf/Cover\%20Crops/Using\%20Cover_crops\%20SAG \%2008\%2009.pdf

88 Footnote 84.

89 National Resources Conservation Service. United States Department of Agriculture. National Handbook of Conservation Practices. Cover Crops and Soil Health. https:/www.nrcs.usda.gov/wps/portal/nrcs/detail/national/climatechange/ ?cid=stelprdb1077238. 
susceptible to wind and water erosion. ${ }^{90}$ The practice generally improves soil quality, particularly porosity and bulk density. It also contributes to soil biology as increased mulching increases earthworm populations and carbon content of soils. ${ }^{11}$ In mulch tillage, tillage methods are used where the soil surface is disturbed to mix crop residue with the soil, hence maintaining a high level of crop residue on the soil surface. Soil is also improved, albeit slowly but steadily, as erosion is reduced and organic matter is increased over time. In the PRC, the lack of natural mulch material has led farmers to use plastic film mulch that warms and retains moisture of plants. While this has raised yields by up to $60 \%$ for cash crops and $30 \%$ for grains, residual plastic harms the soil. Research on purely biodegradable film is needed. ${ }^{92}$

\section{Crop Rotation}

64. This entails growing various crops in a planned sequence in order to increase SOM and biodiversity in the soil. This practice increases nutrient cycling, manages plant pests, reduces erosion, holds soil moisture, and adds diversity so soil microbes can thrive. Crop rotation with legumes in Asia has been declining despite their known benefit of improving soil fertility; this trend has to be reversed to improve productivity. ${ }^{93}$

\section{Nutrient Management}

65. Managing soil nutrients (the amount [rate], source, placement [method of application], and timing of plant nutrients and soil amendments) to meet crop needs while minimizing the impact on the environment and the soil. The practices mentioned above promote the health of soil, enabling the living soil to provide plants the right amount of nutrients when needed.

\section{Pest Management}

66. Managing pests should follow an ecological approach that promotes the growth of healthy plants that have strong defenses and enhance the habitat for beneficial organisms, while increasing stress on pests. In healthy soil, the soil food web naturally provides plants with protection from diseases and pests.

67. The abovementioned farming techniques and soil management practices promote the soil food web that can (i) improve nutrient use efficiency, (ii) decrease pesticide use, (iii) improve water quality, (iv) conserve water, (v) improve plant water efficiency, (vi) improve air quality, (vii) save renewable resources, and (viii) increase plant productivity.

\section{G. Composting and Its Benefits}

68. Composting is an important component of soil management. Composting can find beneficial use for the massive amounts of wastes produced daily. The FAO estimates that approximately 1.3 billion

90 C.J. Baker, K.E. Saxton and W.R. Ritchie. 2002. No-tillage Seeding. Science and Practice. 2nd Ed. United Kingdom: Center for Agriculture and Biosciences International.

91 M.S. Kahlon, R. Lal, and M.A. Varughese. 2013. Twenty Two Years of Tillage and Mulching Impacts on Soil Physical Characteristics and Carbon Sequestration in Central Ohio. Soil Tillage Research. 126. pp. 151-158.

92 E. K. Liu, W. Q. He, and C. R. Yan. 2014. "White Revolution" to "White Pollution"-Agricultural Plastic Film Mulch in China. Environmental Research Letters. 9 (9). http://iopscience.iop.org/article/10.1088/1748-9326/9/9/091001/pdf

93 C. L. L. Gowda, A. Ramakrishna, O. P. Rupela, and S. P. Wani, eds. 2001. Legumes in Rice-Based Cropping Systems in Tropical Asia: Constraints and Opportunities. Patancheru. 502 324. Andhra Pradesh: International Crops Research Institute for the Semi-Arid Tropics. 
tons or a third of global food production gets lost or wasted annually. ${ }^{94}$ In fact, an average person generates about 2 kilos of waste per day, up from roughly 0.7 kilos in the 1960s. Roughly two-thirds of household wastes can be used as materials for composting. Composting is important as it turns wastes into manageable and valuable material.

69. Composting is the controlled decomposition (aerobic degradation) of organic materials by microorganisms. The product is compost, a soil-like substance of partially decomposed organic matter, as opposed to humus, which is completely decomposed organic matter. ${ }^{95}$ Like any undertaking, composting requires time and commitment. When done right, the compost has no bad odors, stores well, and is biologically stable.

70. Materials for composting include plant and animal materials, such as crop residues, animal manure, peelings, food waste, yard waste, and recycled papers without glossy or colored inks. Not all waste products, however, are suitable for composting, such as fish scraps, sewage, dairy products, cooked food wastes, and human excrement. Unlike the former, these materials require special treatment to kill disease-causing organisms and treat toxic materials, and often are very slow to compost. ${ }^{96}$

71. Compost can be used as mulch, soil amendment, and a source of organic matter. It can improve both soil health and quality. Applying compost to soil can (i) increase microbial activity, (ii) enhance plant disease suppression, (iii) increase soil fertility, (iv) increase cation exchange capacity, (v) improve soil structure in clayey soils, (vi) improve water retention in sandy soils, and (vii) reduce bioavailability of heavy metals. ${ }^{97}$

72. Microorganisms are the key players in the composting process, hence optimal conditions for microbial activity are best observed to ensure proper composting. ${ }^{98}$

73. The type of method chosen for composting should reflect a number of factors, such as needs, available space, materials, time, and manageability of compost pile. For people with little space and time, materials can be placed in holding units or piled as heaps. However, this process has a slow rate of decomposition, about a year or two, which gives more chances for pests to excavate buried wastes. This process does not destroy weed seed or plant pathogens. By contrast, turning units that are designed to be turned or aerated can kill bacteria and produce compost, which can increase SOM in 2 months or less. ${ }^{99}$

74. The hot or fast method of composting requires more management than the cold or slow method but can best control weed seed and plant pathogens. Using earthworms for composting or vermicomposting is good for food scraps. A pound of worms can compost 65 pounds of material in

94 Food and Agriculture Organization. SAVE FOOD: Global Initiative on Food Loss and Waste. http://www.fao.org/savefood/resources/keyfindings/en/.

95 University of Florida. Florida's Online Composting Center. http://sarasota.ifas.ufl.edu/compost-info/tutorial/what-iscomposting.shtml

96 University of Illinois Extension. Composting for the Homeowner-Benefits and Uses. http://web.extension.illinois.edu/ homecompost/benefits.cfm

97 E. Marriott and E. Zaborski. 2015. Making and Using Compost for Organic Farming. http://www.extension .org/pages/18567/making-and-using-compost-for-organic-farming\#.VizVd34rldU

98 University of Florida. Florida's Online Composting Center. http://sarasota.ifas.ufl.edu/compost-info/tutorial/what-is -composting.shtml

99 University of Illinois Extension. Composting for the Homeowner-Composting Methods. http://web.extension .illinois.edu/homecompost/methods.cfm 
100 days. The best worms for composting are the red-wigglers and African night crawlers. ${ }^{100}$ Given the massive scale of daily household wastes, households should be knowledgeable and practice composting. Suitable composting method can be designed to meet specific conditions of households and communities.

\section{POLICY RECOMMENDATIONS TO PROMOTE HEALTHY SOILS}

75. As has been emphasized at the United Nations Framework Convention on Climate Change (UNFCC), fighting climate change requires a comprehensive strategy with a portfolio of actions involving multiple partners particularly governments, donors, private companies, research institutes, farmers' organizations, and NGOs. Partners can engage in programs of action for better soil carbon management to fight food insecurity and poverty while contributing to climate change adaptation and mitigation, and undertake international research and scientific cooperation program on the subject.

76. Complementing the UNFCC agenda of arresting climate change, the role of soil is emphasized in the Lima-Paris Action Agenda, which proposed better understanding of the whole gamut of soil carbon sequestration. To this end, research should be focused on four complementary themes: (i) mechanisms and assessment of carbon storage potential in soils across regions and systems; (ii) performance evaluation of best farming practices for soil carbon and impact on other GHGs, food security, and other regulation and production services; (iii) innovation and its promotion by appropriate policies; and (iv) monitoring and estimating variations in soil carbon stock, especially at farmers' level.

77. Partners in their respective capacities, where applicable, are enjoined to (i) implement agricultural practices and manage environments that restore soils, increase organic carbon stock, and protect carbon-rich soils and biodiversity at local levels; (ii) implement training and outreach programs to encourage such practices; (iii) finance projects that restore, improve, and/or preserve carbon stocks in soils; (iv) develop and implement public policies and appropriate tools; and (v) develop supply chains of soil-friendly agricultural products.

78. Based on the 4 Per 1000 Initiative, governments are encouraged to support the transition of agricultural systems toward regenerative agriculture by providing appropriate training and enacting appropriate regulations and policy tools. Specific policies may include compensation schemes for farmers who practice regenerative farming, and provide subsidies and tax credits to farmers who promote healthy soils and natural pest management. Support and subsidies to harmful practices (e.g., chemical fertilizer subsidy) should be stopped. Local governments and grassroots organizations are also key players in raising awareness at schools and public spaces on practices that promote healthy soils, such as banning of the burning of crop residue and biomass.

79. Women have key roles to play in farming households, particularly in poor rural areas. Governments should craft and/or implement gender-sensitive policies that support the role of women in promoting healthy soils. Women in agricultural communities are often assigned tasks on household food production, family health and nutrition, and management of natural resources; and soil plays an important role in the performance of these tasks. Training on managing healthy soil, targeting rural women, and related support services and appropriate technologies that ease farming work should be promoted not only by governments but also by NGOs. Donors and private entities are encouraged to support development projects that support soil health and soil carbon sequestration, while private

100 Footnote 92. 
companies should eliminate from their supply chains products that are not compatible with objectives of promoting soil health. Specific actions of donors and firms may include supporting certification of regenerative production systems, and product promotion and marketing.

80. Farmers' organizations are crucial in encouraging their member farmers to adopt new agricultural practices to store a larger amount of carbon. These would help farmers better address their needs in achieving healthy soils if governments engage them in policy dialogues on issues regarding soil health. NGOs have key roles to play in identifying and facilitating the dissemination of good practices in soil management, and ensuring that they meet expectations of soil carbon sequestration. In particular, the practice of no-tillage and no-chemical farming should be promoted by extension workers and NGOs, as this method allows soil organisms to flourish and effectively recycle nutrients; and prevents runoffs that pollute water and soil. Farmers should likewise receive training to develop nutrient management plans suitable for their respective crops and local conditions to effectively recycle nutrients and carbon.

81. In many countries, soil health programs are supported through organic agriculture promotion programs. Examples of policy instruments to support organic agriculture sector include (i) laws and regulations for organic production; (ii) financial instruments such as producer support by areas payment, inspection cost support, investment grant, etc.; and (iii) communication instruments such as information and promotion campaign, public education, demonstration plots, etc.

82. In December 2015, at the 21st Session of the Conference of the Parties of the United Nations Climate Change Conference in Paris, 195 countries adopted the first universal and building global climate action plan. In support of reaching an international agreement, countries are invited to submit their Intended Nationally Determined Contributions (INDCs) outlining the countries' intended actions to be implemented between 2020 and 030. As agriculture and natural resources is the key sector in the GMS countries, promotion of sustainable and climate-resilient or climate-proof farming systems, including disaster risk management are prioritized actions in INDCs of all GMS countries. While INDC documents do not get into specific details, it is well understood that attention to restoring natural resources such as soil and water forms the foundation of climate-resilient development. ${ }^{101}$ It is noted that in the INDC of Viet Nam, enhancing of soil carbon sequestration is explicitly stated. As awareness on soil as a solution to climate change increases among international, public, and private sector in these countries, financial resources as well as capacity building and technical transfer will further highlight soil solution in the INDCs of these countries.

\section{CONCLUSION}

83. The ground under our feet is teeming with life. Despite its ubiquity, the importance of a highly diverse community of life underground is hardly noticed. Both visible and invisible organisms in the soils have key roles to perform in fulfilling specific nutritional needs of plants while performing myriad ecosystem services, including carbon sequestration, water purification and soil contaminant reduction, climate regulation, nutrient cycling, habitat for organisms, flood regulation, source of genetic resources and pharmaceuticals, and provision of food, fuel and fiber. Soil is also the foundation for and source of material for human infrastructure.

101 Center for Climate and Energy Solutions. Comparison Table of Submitted INDCs (as of 21 December 2015). http://www.c2es.org/indc-comparison 
84. Soil as a resource has been greatly abused and degraded by man. With the pressing challenge of climate change and food insecurity, now is the time to bring back life to soil. Foremost is raising awareness in everyone, utilizing both modern and traditional information technology media on the importance of soil to sustaining life in this planet. With awareness, it is hoped that action will come next that will protect and restore soil health.

85. Actions of local and international public and private sector in supporting green growth through building new markets, and through political and social structures, are urgently needed. With growing recognition that large-scale restoration of soil health can effectively and efficiently facilitate the achievement by countries of their INDC targets, climate financing sources such as the Asian Development Bank's Green Climate Fund will prioritize such investment in countries' climate investment plans.

86. With or without external financing, actions of governments are necessary, particularly in establishing national comprehensive programs on healthy soil for climate, water, and human health. The program would include investment not only in agriculture sector in building capacity for extension workers and farmers but also investment in other sectors, e.g., education sector in curriculum development, health sector in monitoring nutritional quality and safety of food, and climate change agencies to monitor soil carbon. Private sector firms with business models that enhance soil health should also be supported to mainstream their operations to sustain the impacts.

87. Soil health is also central in feeding a growing global population. Agricultural lands that produce the many bounties of nature depend on soil health for sustainability. Soils produce crops on a massive scale that feed both humans and animals. However, the current agricultural production practices of intensified production based on mechanical tillage have little regard to enhancing soil health. Increasing soil and water degradation compounded by a warming climate that increases water scarcity, endangers food security both now and in the future.

88. Modern agriculture practices over the last 6 decades had led to changes in the balance of carbon and nitrogen cycles, which consequently have depleted soil organic carbon and exacerbated global climate change. Fortunately, regenerative agriculture practices also provide an opportunity for sequestering carbon back into the soil, while potentially improving human health. Farmers and rural communities are the first to suffer from the damage to health, biodiversity, and ecosystems due to climate change. At the same time, farmers can also be key players in reversing climate change through their agriculture practices. It is urgent that proper incentives and rewards be put in place for them to restore soil health, including soil carbon, so they could be the first to reap the benefit of restored physical health and that of the natural environment, which they depend on for livelihood.

89. Finally, the fight against climate change has room for all. Everyone can be a part of a global soil restoration movement that offers practical solution to climate change, bearing in mind that promoting healthy soils is a not just a strategy for those with access to land. Individuals as consumers can show support by purchasing products of regenerative farming and organic produce. Individual actions when taken collectively can become a palpable force in arresting climate change. 


\section{Large-Scale Soil Health Restoration: The Way Forward for Reversing Climate Change while Enhancing Food and Nutrition Security}

This paper describes what is soil health, and lists soil-regenerative agriculture practices that can mitigate and reverse climate change, improve water management, and enhance food and nutrition security. Soil has been overlooked as a natural resource yet it can be an ally in bringing carbon dioxide levels down by being a carbon sink. Healthy soil increases the adaptive capacity of plants to withstand extreme weather conditions, lessening crops failures, making it essential to fight malnutrition, particularly in rural areas.

\section{About the Asian Development Bank}

ADB's vision is an Asia and Pacific region free of poverty. Its mission is to help its developing member countries reduce poverty and improve the quality of life of their people. Despite the region's many successes, it remains home to a large share of the world's poor. ADB is committed to reducing poverty through inclusive economic growth, environmentally sustainable growth, and regional integration.

Based in Manila, ADB is owned by 67 members, including 48 from the region. Its main instruments for helping its developing member countries are policy dialogue, loans, equity investments, guarantees, grants, and technical assistance. 